\title{
Wisdom and Altruism in Entrepreneurship: Comparing Social Entrepreneurs to Commercial Entrepreneurs
}

\author{
Selma ARIKAN (iD) a Ezgi YILDIRIM SAATÇI iD b \\ a İstanbul Medeniyet University, Department of Psychology, İstanbul, Turkey. selma.arikan@medeniyet.edu.tr \\ b İstanbul Okan University, Department of Business Management, İstanbul, Turkey. ezgi.saatci@okan.edu.tr
}

\begin{tabular}{ll}
\hline ARTICLE INFO & ABSTRACT \\
\hline Keywords: & $\begin{array}{l}\text { Purpose - Besides philosophers, today wisdom has been a subject of inquiry for psychologists, } \\
\text { management scientist and other social scientists as well. We tried to understand the role of wisdom }\end{array}$ \\
$\begin{array}{l}\text { Cocial Entrepreneurship } \\
\text { Wisdom }\end{array}$ & $\begin{array}{l}\text { in entrepreneurship by comparing the social entrepreneurs to commercial entrepreneurs by using } \\
\text { Altruism }\end{array}$ \\
3 Dimenika Ardelt's (2003) Three Dimensional Model of Wisdom. In addition, the association of wisdom \\
dimensions to altruism was scrutinized for both entrepreneur groups.
\end{tabular}

\section{INTRODUCTION}

Entrepreneurship and social entrepreneurship has been an interesting topic for researchers in the last decades. As SME's importance increase in today's economies in creating new ideas and jobs, governments introduce procedures and legislations that help to create entrepreneurship climate and cultures. Today various international or local organizations, development agencies offer programs about financial models, mentoring in entrepreneurship or provide micro credits to the potential entrepreneurs. In terms of education, even some high schools have compulsory entrepreneurship courses in their curriculum. Entrepreneurship is becoming a more salient phenomenon as it has the potential to create new opportunities of employment in economies like Turkey where the rate of youth unemployment is high (Saatçi and Arıkan, 2014).

Entrepreneurship is defined in Oxford Dictionary as "The activity of setting up a business or businesses, taking on financial risks in the hope of profit". From this definition we can define the entrepreneur as a person who starts up a new business via investing on this business by taking financial risks and expects to make profits and gains in the future. According to OECD entrepreneurship can be defined as follows "Entrepreneurs are agents of change and growth in a market economy and they can act to accelerate the generation, dissemination and application of innovative ideas... they not only seek out and identify potentially profitable economic opportunities but are also willing to take risks to see if their hunches are right" (OECD, 1998, p.11).

\section{Suggested Citation}

Arıkan, S., Yıldırım Saatçi, E. (2021). Wisdom and Altruism in Entrepreneurship: Comparing Social Entrepreneurs to Commercial Entrepreneurs, Journal of Business Research-Turk, 13 (3), 1935-1944. 
Commercial entrepreneurship and social entrepreneurship are two different forms of entrepreneurship in today's world. Despite some differences social entrepreneurship also shares some of the principles of commercial entrepreneurship, especially in terms of the business setting up processes. Similar to business and profit oriented commercial entrepreneurship, social enterprises also pass from the stand up, start up, scale up phases. Opportunity recognition, creativity and innovativeness, access to funding, taking risks, inspiration to start an organization, planning are common characteristics in both commercial entrepreneurship and social entrepreneurship. But what is the difference between the two types of entrepreneurship and how these entrepreneurs are different from each other are the key questions to answer. Mainly the difference lies on the orientation of the entrepreneurs and their organizations. The internal motivation of social entrepreneurs seems to be different from the commercial entrepreneurs. Instead of profit maximization social entrepreneurs are basically concerned with solving social problems, social transformations, and creating social values for the society (Pal Singh, 2007; Saatçi and Arıkan, 2014; Saatçi, Arıkan and Çal, 2014). In this research we aimed to investigate the antecedents of this internal motivation to create organizations for ameliorating the conditions for the well-being of others, by comparing the social entrepreneurs to the ordinary commercial entrepreneurs.

The previous researchers and scholars differentiated social entrepreneurs from commercial entrepreneurs in terms of achieving long-standing social gains (Lumpkin, Moss, Grass, Kato, and Amezcua, 2013); considering social needs in the society and trying to maximize social welfare (Pirson, 2012); sustainability of solutions and satisfying multiple stakeholders (Di Domenico, Haugh and Tracey, 2010); and addressing social problems and needs of people (Omorede, 2014). All these notions imply that instead of profit maximization, social entrepreneurs are involved with solving social problems, improve other peoples and sometimes animals' lives for better societies and life. It seems that, it is a kind of altruistic capitalism, it tries to solve the problems of the disadvantaged groups by using the mechanisms of market economy to create a social value.

"What are the differences between commercial entrepreneurs and social entrepreneurs?" is the basic question of this research and from the literature regarding social entrepreneurship, wisdom and altruism; we decided to investigate these personal qualities in entrepreneurs by comparing social entrepreneurs to commercial entrepreneurs. As the definition and dimensions of wisdom are related with understanding life, giving the right decisions for the well-being of all the parties and living creatures in one hand; and as altruism is associated with feeling empathy and helping others on the other hand; we chose to inquire those two constructs to understand their effects on the types of entrepreneurship chosen. Wisdom and altruism have the potential to explain the different motivations that those two types of entrepreneurs have while setting up their businesses.

\section{Literature Review}

\subsection{Wisdom}

Besides philosophers today wisdom has been a subject of inquiry for psychologists, and other social scientists as well. Although wisdom research has gained popularity over the past two decades, a generally agreed on definition does not exist yet. Various definitions are available among philosophers, social scientists, and psychologists. A well-known definition from Sternberg covers the term well and according to him wisdom is "The application of tacit knowledge as mediated by values toward the achievement of a common good through a balance among multiple (a) intrapersonal, (b) interpersonal, and (c) extra personal interests in order to achieve a balance among (a) adaptation to existing environments, (b) shaping of existing environments, and (c) selection of new environments." (Sternberg 1998:347). In this definition Sternberg emphasizes the balance among multiple stakeholders' interests other than self-centeredness. Wisdom of the social entrepreneurs may be an important factor that differentiate them from profit and self-gain oriented commercial entrepreneurs.

Today there exist a consensus that wisdom is a multidimensional concept and each dimension reinforces the others (Baltes and Staudinger, 2000; Ardelt, 2003, Ardelt, 2011). According to Ardelt (2003) wisdom is a three dimensional concept and it is formed by the unification of cognitive, reflective, and affective dimensions. To comprehend how wisdom can be related with entrepreneurship, especially with social entrepreneurship, it is important to understand what those three dimensions of wisdom cover. 


\section{Reflective Dimension of Wisdom:}

According to Ardelt the first dimension of wisdom is the reflective dimension, and she emphasized that reflective dimension seemed to be a prerequisite for the development of the cognitive dimension (Ardelt 2003). Reflective dimension is related with a deep, universal, and comprehensive way of thinking and understanding. She claimed that reflective dimension of wisdom covers perceiving reality without any distortions, being free of personal prejudices and expectations and examining phenomena and events from many different perspectives to understand how the phenomena effect others' lives. But to achieve this, a reflective person should develop a self-insight and self-awareness first. To be a reflective person requires knowing himself/herself similar to what Anatolian Sufi Yunus Emre once had said "Wisdom and science is knowing yourself". Practicing reflective thinking, and conceiving deeply is important to overcome subjectivity and reducing self-centeredness, subjectivity and projections. Reflective thinking is the key for increasing insight about the true nature of the things and events. Reflection leads us to understand our own motives and human nature which also supports our understanding of other people's motives and behaviors. As a result of reflective thinking wise people achieve to be less self-centered and they can better understand others' and their own needs and behavior (Ardelt, 2003; Ardelt 2011). Especially for social entrepreneurship overcoming self-centeredness might be an important factor since those entrepreneurs set up their businesses without the aim of gaining more money for their own.

\section{Cognitive Dimension of Wisdom:}

Ardelt (2003) believes that cognitive dimension of wisdom is concerned with the person's ability to understand life. Wisdom requires understanding the significance and deeper meaning of facts and events (Ardelt, 2000). Cognitive dimension of wisdom covers to appreciate human nature and being aware of the positive and negative aspects of human nature and life. Wise people are known to be aware of the limits of their own and human nature's capacities and knowledge and they can acknowledge life's unpredictability and uncertainty (Ardelt, 2003; Ardelt, 2011).

\section{Affective Dimension of Wisdom:}

Affective dimension of wisdom is related with feelings of sympathy and compassion for other living things. Not only has it contained the presence of positive emotions and behavior towards other people but other beings as well. It requires the absence of negative emotions and behaviors toward others. It is related with caring for all people and all living things (Ardelt, 2003; Ardelt, 2011).

\subsection{Wisdom and Entrepreneurship}

We believe that wisdom and social entrepreneurship should be associated to each other as social entrepreneurs are concerned with solving social problems, they create businesses for creating social values for the society rather than profit maximization. Social entrepreneurs reevaluate the social problems from different perspectives and find new and sustainable solutions.

As social entrepreneurs are less self-centered and less profit oriented in their businesses, and feeling more empathy to others and their problems, and these qualities are important for perceiving, understanding and finding solutions to social problems; we expect that social entrepreneurs should have higher qualities of wisdom compared to profit oriented commercial entrepreneurs. We expect this difference especially for the affective dimension of wisdom since emotions play a crucial role in human motivation. Hence our first hypothesis is:

$H_{1}$ : Social entrepreneurs have higher scores of wisdom compared to commercial entrepreneurs.

\subsection{Altruism}

Altruism is mainly a topic for evolutionary psychology and the studies are concerned with how these sometimes self-sacrificing trait evolved despite to the natural selection of many selfish habits. Thanks to the Hamilton's (1964) inclusive fitness theory, in today's evolutionary perspective altruism is not a contradiction for evolution (Buss, 2011; Taylor, 1992). As altruism basically helps the wellbeing and survival of the others; generally these are the people that we share common genes; it helps the sustainability of the relatives, common genes and provides the survival of the species (Buss, 2011; Hamilton, 1964; Trivers, 1971). Altruism is also an area of inquiry for social psychology (Taylor, Peplau, and Sears, 2006). Various definitions are available for 


\section{S. Arıkan - E. Yıldırım Saatçi 13/3 (2021) 1935-1944}

altruism (as cited in Batson and Powell, 2003) and these definitions mainly emphasized the following issues. Altruism is helping others in the absence of obvious external rewards, altruism is related with the motivation to increase another person's welfare and it is generally positioned on the opposite of egoism and egoist characteristics.

Rushton, Chrisjohn, and Fekken (1981) claimed that there is a consistency of altruistic behaviors across conditions showing that there is a trait of altruism and offered the concept of altruistic personality. They also developed the 20 item Self -Report Altruism Scale to measure altruistic personality. Other oriented cognitive and affective tendencies, sympathy, social responsibility, other oriented concern, ascribing responsibility, and feeling empathy are claimed to be related with altruistic personality (Carlo, et al., 1991). People with altruistic tendencies/personality behave more pro-socially, although there seems to be an interaction between situation and personality (Bierhoff and Rohmann, 2004; Carlo et al., 1991). One of the most frequently pronounced views about altruism is "The Empathy-Altruism Hypothesis" by Batson (Batson, et al., 1991). According to Batson altruism is related with other-oriented emotions which are in congruence with the perceived welfare of other person and empathy (Batson, 1987).

Altruism is associated with empathic emotions like sympathy, compassion and affection that give rise to motivation for behaviors benefiting and helping the other person for whom the empathy is felt. Previous studies also support that feeling empathy is related with helping and altruistic behaviours (Batson, Ahmad, Stocks 2004; Graziano, Habashi, Sheese and Tobin 2007; Huber, and MacDonald, 2012).

\subsection{Altruism and Social Entrepreneurship}

The association between altruism and social entrepreneurship was previously mentioned among the scholars in social entrepreneurship research. Tan and friends denoted that social entrepreneurship is the promise that entrepreneurship could be aimed at benefiting society and helping in need rather than profit making. According to them social entrepreneurship is an altruistic form of capitalism (Tan, Williams and Tan, 2005). Mair and Marti also emphasized the altruistic characteristics in entrepreneurs' behaviors, and claimed that social entrepreneurship was a kind of expression of altruism for these entrepreneurs (Mair, and Marti, 2006). Martin and Osberg (2007) also implied that social entrepreneurs can be said to be driven by their altruistic characteristics. Miller and collegues also differentiated social entrepreneurs from the commercial entrepreneurs as social entrepreneurs' main focus is on creating social value, helping others in need and benefiting the general society rather than increasing his/her economic gains (Miller, Grimes, McMullen, and Vogus, 2012) Hence we hypothesized that:

$\boldsymbol{H}_{2}$ : Compared to commercial entrepreneurs social entrepreneurs score higher in altruism scale and in its sub dimensions.

In addition to these hypothesis, this research aimed to shed light on the differences in terms of wisdom and altruism relationship between these two different entrepreneurship groups: profit oriented vs social benefit oriented entrepreneurs. In the light of the literature about wisdom and altruism it was expected that wisdom could explain the variance in altruism, and these explanations could be different for different groups of entrepreneurs such as reflective and affective dimensions of wisdom might better explain social entrepreneurs' altruistic tendencies compared to commercial entrepreneurs. As we previously mentioned; reflective dimension of wisdom is the key factor to overcome egocentrism and self-centeredness, and affective dimension of wisdom is related with feelings of empathy and compassion towards others. Hence social entrepreneurs' altruistic tendencies might be strongly related and predicted with these two dimensions of wisdom. Moreover social entrepreneurs act with less egocentrism, less profit orientation and more compassion towards others with their entrepreneurial actions. In social psychology it is known that the attitudes are comprised of cognitive, emotional and behavioral aspects. Only for the strongest attitudes there is high consistency among those three components; the stronger the attitude, the more likely it is reflected as an action and behavior by the attitude owner (Kağıtçıbaşı, 2010). Social entrepreneurs less egocentric and more compassionate attitudes must be stronger, as they are shown in action, than the commercial entrepreneurs according to classical attitude theories in social psychology. As a result of this, social entrepreneurs' altruistic tendencies might be more strongly predicted by reflective and affective dimensions of wisdom compared to commercial entrepreneurs'. So we expected that: 
$H_{3 a}$ : Wisdom scores predict the altruistic tendencies (altruism scores) of both commercial and social entrepreneurs.

$H_{3 b}$ : The reflective and affective dimensions of wisdom explain the altruistic tendencies of social entrepreneurs better than the commercial entrepreneurs.

\section{METHOD}

\subsection{Participants}

Participants were reached through the networks in various universities entrepreneurship departments. They were categorized according to their business projects either commercial or social. Totally 350 entrepreneurs participated to our study. The preliminary results of this study was presented in an oral presentation session in EAWOP (European Association of Work and Organizational Psychology) 2017 conference that took place in Dublin in Ireland. The composition of the participants consisted either students or newly graduated students that were taking consultancy services from the entrepreneurship centers of the universities. All the participants were at the passage from standup to startup phase of firm formation. 204 of those participants were classified as commercial entrepreneurs and other 146 participants as social entrepreneurs. 172 of the participants were females and 178 were males. In terms of marital status the majority (342 over 350) of the participants were single as the participants were selected from the young age group that are at the beginning of their career $(96 \%$ under the age of 25 , with a mean age of 20.34 , sd: 2,97$)$. Only seven of the participants were married.

\subsection{Measurement}

Survey methodology was used to gather the research data and a Demographic Questions form and the other two scales were included in the leaflets that were given to the participants.

\section{Demographic Questions Form:}

These question form included questions regarding the age, gender, marital status, job experiences of the participants. The participants were divided into two as commercial entrepreneurs and social entrepreneurs by the experts employed in the entrepreneurship centers of the universities that these participants applied to, in regard to the contents and aims of their businesses.

\section{Three Dimensional Wisdom Questionnaire:}

Monika Ardelt's (2003) 3D -WS (Three Dimensional Wisdom) questionnaire which includes 39 items was used to measure wisdom. The item distribution into dimensions are as follows: 14 items measure the cognitive dimension, 12 items are prepared for reflective dimension and 13 are for affective dimension of wisdom. The participants were asked to evaluate the sentence in each item from "1: completely disagree" to "6: completely agree". Internal reliability coefficients for all dimensions in this study was found as follows (Cronbach $\alpha$ for Cognitive dimension:.76, Cronbach $\alpha$ for Reflective dimension :.79 and Cronbach $\alpha$ for Affective dimension $: .80)$

\section{Self-Report Altruism Scale:}

Altruistic characteristics of the participants were measured via 20 item Self-Report Altruism Scale of Rushton et al. (1981). The participants were asked to evaluate each item with a 5 point Likert scale from "1: Never" to "5: Frequently". An exploratory factor analysis was conducted to the scale resulting with 5 subdimensions. The subdimensions and their Cronbach $\alpha$ coefficients were found as follows: Tenderness: Cronbach $\alpha: .79$, Helpfulness: Cronbach $\alpha$ : .78, Benevolence (without costs): Cronbach $\alpha$ :. 70, Benevolence (with costs): Cronbach $\alpha$ : .70, and Authenticity: Cronbach $\alpha: .67$.

\subsection{Data Analysis}

The data was analyzed by using IBM SPSS Statistics 21. Program. Pearson $r$ correlations, multiple regression analyses, and independent samples $\mathrm{t}$-tests were conducted to test the hypothesis. 


\section{RESULTS}

To test Hypothesis 1 "Social entrepreneurs have higher scores of wisdom compared to commercial entrepreneurs" participants that were classified as social entrepreneurs were compared to commercial entrepreneurs by using independent samples t-tests. The results showed that social entrepreneurs had higher scores for the cognitive

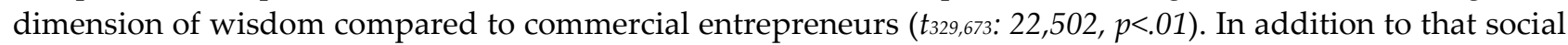

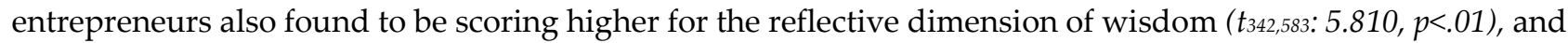

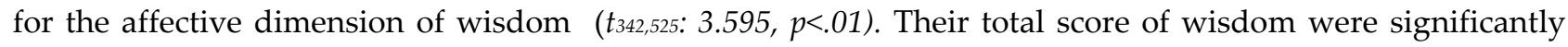

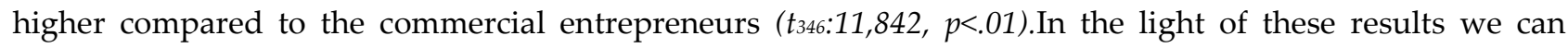
confidently say that Hypothesis 1 is supported.

Similarly independent samples t-tests were also conducted for the altruism scale to test Hypothesis 2: "Compared to commercial entrepreneurs social entrepreneurs score higher in altruism scale and in its sub dimensions". Social entrepreneurs had significantly higher scores in the altruism scale $\left(t_{343,122: 3.416, p<.01)}\right.$ compared to commercial entrepreneurs. Regarding the sub dimensions of altruism scale independent samples t-tests again showed results in congruence with our hypothesis. Social entrepreneurs had significantly higher scores for the tenderness $\left(t_{348}: 3.780, p<.01\right)$, helpfulness $\left(t_{336,088:} 2.597, p<.05\right)$, benevolence (with costs) $\left(t_{337,677: 2,012, p<.05)}\right.$ and authenticity $\left(t_{348}: 3.324, p<.01\right)$ dimensions of the altruism scale. In terms of benevolence (without costs) dimension of altruism, no significant difference was found between two groups. Both the results of the analysis regarding Hypothesis 1 and Hypothesis 2 are presented in Table 1.

Table 1: Comparison of Social Entrepreneurs to Commercial Entrepreneurs in terms of Wisdom and Altruism:

\begin{tabular}{lcccccc}
\hline Variable & Group & $\mathrm{N}$ & $\mathrm{Mean}$ & $\mathrm{df}$ & $\mathrm{t}$ & $\mathrm{p}$ \\
\hline Wisdom & Soc. & 145 & 3,20 & 346 & 11,842 & .000 \\
& Com. & 203 & 2,57 & & & \\
Cognitive W. & Soc. & 146 & 3,05 & 329,673 & 22,502 & .000 \\
Reflective W. & Com. & 204 & 2,00 & & & \\
\multirow{4}{*}{ Affective W. } & Soc. & 145 & 3,34 & 342,583 & 5,810 & .000 \\
Altruism & Com. & 204 & 2,85 & & & \\
& Soc. & 146 & 3,23 & 342,525 & 3,595 & .000 \\
Tenderness & Com. & 203 & 2,92 & & & \\
& Soc. & 146 & 3,15 & 343,122 & 3,416 & .001 \\
Helpfulness & Com. & 204 & 2,88 & & & \\
& Soc. & 146 & 3,42 & 348 & 3,780 & .000 \\
Benevolence (no material) & Com. & 204 & 2,93 & & & \\
\multirow{2}{*}{ Benevolence (inc. material) } & Soc. & 146 & 3,06 & 336,088 & 2,597 & .010 \\
\multirow{2}{*}{ Authenticity } & Com. & 204 & 2,79 & & & \\
& Soc. & 146 & 3,17 & 344,535 & 1,146 & .253 \\
& Com. & 204 & 3,06 & & & \\
& Soc. & 146 & 3,14 & 337,677 & 2,012 & .045 \\
\hline
\end{tabular}

To test our third hypothesis " $H_{3 a}$ : Wisdom scores predict the altruistic tendencies (altruism scores) of both commercial and social entrepreneurs" and " $H_{3 b}$ : The reflective and affective dimensions of wisdom explain the altruistic tendencies of social entrepreneurs better than the commercial entrepreneurs" one simple regression and three multiple regression analyses by using stepwise method were conducted. First of all a simple regression analysis was conducted to test whether wisdom scores of the entrepreneurs predicted their altruistic tendencies and $\mathrm{H}_{3 \mathrm{a}}$ was supported $\left(R^{2}: .20, F: 85,227, \beta: .445, t: 9,232, p<.001\right)$. Then three multiple regression analyses were conducted; one for all participants, one for commercial entrepreneurs and another for social entrepreneurs. The multiple regression analysis for all entrepreneurs yielded a significant result showing that reflective $(\beta: 312, t: 5.624, p<.001)$ and affective dimensions of wisdom ( $\beta: 273, t: 4.932, p<.001)$ were explaining $26 \%$ of the variance in altruism scores $\left(R^{2}: 26, F: 62,5, p<.001\right)$. 


\section{S. Arıkan - E. Yıldırım Saatçi 13/3 (2021) 1935-1944}

In the multiple regression analysis to understand the associations between wisdom dimensions and altruism for commercial entrepreneurs, different results were found. This time, affective and cognitive dimensions of the wisdom entered the regression equation explaining the altruism. These two dimensions were significantly explaining $29 \%$ of the total variance in altruism scores $\left(R^{2}: .29, F: 41.294, p<.001\right)$. Despite the positive effect of affective dimension on altruism ( $\beta: .492, t: 8.274, p<.001)$, cognitive dimension was found to have a negative relation with altruism ( $\beta:-.209, t:-3.508, p<.01)$.

For social entrepreneurs the results of the multiple regression analysis was in parallel with all participants results. Reflective $(\beta: .452, t: 6.087, \beta<.001)$ and affective $(\beta: .152, t: 2.041, p<.05)$ dimensions of wisdom found to be significantly predicting the altruism scores for social entrepreneurs explaining $27 \%$ of total variance $\left(R^{2}: .27, F: 25.823, p<.001\right)$. These findings support $\mathrm{H}_{3 a}$. As the $\beta$ value of the affective dimension of wisdom is lower for the social entrepreneurs $\mathrm{H}_{3}$ b was only partially supported for the reflective dimension of wisdom. The results of these multiple regression analysis are presented in Table 2.

Table 2: Dimensions of Wisdom Explaining the Variance in Altruism

\begin{tabular}{|c|c|c|c|}
\hline \multicolumn{4}{|l|}{ For All Entrepreneurs: } \\
\hline \multirow{4}{*}{$\begin{array}{l}\text { Dependent Variable } \\
\text { Independent Variables: } \\
\text { R2:.27 Adjusted R²: .26 } \\
\text { Variables in Equation }\end{array}$} & \multicolumn{3}{|l|}{ Altruism } \\
\hline & \multicolumn{3}{|c|}{ Wisdom Cognitive, Wisdom Reflective, Wisdom Affective } \\
\hline & F: 62,550 & & p: .000 \\
\hline & B & $\mathbf{T}$ & $\mathbf{p}$ \\
\hline Wisdom Reflective & .312 & 5,624 & .000 \\
\hline Wisdom Affective & .273 & 4,932 & .000 \\
\hline \multicolumn{4}{|l|}{ For Social Entrepreneurs: } \\
\hline \multirow{2}{*}{$\begin{array}{l}\text { Dependent Variable: } \\
\text { Independent Variables: }\end{array}$} & \multicolumn{3}{|l|}{ Altruism } \\
\hline & \multicolumn{3}{|c|}{ Wisdom Cognitive, Wisdom Reflective, Wisdom Affective } \\
\hline Adjusted $\mathbf{R}^{2}: .24$ & $\mathbf{F}: 25,823$ & & p: .00 \\
\hline Variables in Equation & B & $\mathbf{T}$ & p \\
\hline Wisdom Reflective & .454 & 6,087 & .000 \\
\hline Wisdom Affective & .152 & 2,041 & .043 \\
\hline \multicolumn{4}{|l|}{ For Commercial Entrepreneurs } \\
\hline \multicolumn{4}{|c|}{$\begin{array}{ll}\text { Dependent Variable } & \text { Altruism }\end{array}$} \\
\hline Independent Variables: & \multicolumn{3}{|c|}{ Wisdom Cognitive, Wisdom Reflective, Wisdom Affective } \\
\hline Adjusted R2:.29 & F: 41,294 & & p: .000 \\
\hline Variables in Equation & B & $\mathrm{T}$ & $\mathrm{p}$ \\
\hline Wisdom Affective & .492 & 8,274 & .000 \\
\hline Wisdom Cognitive & -.209 & $-3,508$ & .001 \\
\hline
\end{tabular}

\section{DISCUSSION}

The analyses comparing both groups showed that social entrepreneurs had significantly higher scores in all dimensions of wisdom (Cognitive, Reflective and Affective) in congruence with our expectations. As social entrepreneurs are concerned in solving the problems of other people in the society for better lives, social entrepreneurs could be more successful to understand the social problems. They cogitate on societies' problems, feel empathy for the groups in need and find applicable and sustainable solutions. These all require cognitive, reflective and affective capabilities of the wisdom.

The mean of total altruism scores of social entrepreneurs were significantly higher than commercial entrepreneurs. In addition to that all altruism dimensions, except for benevolence without material costs, social entrepreneurs scored higher than commercial entrepreneurs. It seems that social entrepreneurs are more altruistic and that finding is consistent with the main difference of two groups: rather than profit maximization social entrepreneurs are motivated with social value maximization. These findings also imply that when there is no monetary cost for the commercial entrepreneurs they can behave altruistically and benevolently like social entrepreneurs, on the other hand when there is a risk of losing money they seem to hesitate to be altruistic and benevolent. These findings have also an implication for future studies on the differences of materialistic values between the social entrepreneurs and commercial entrepreneurs. 


\section{S. Arıkan - E. Yıldırım Saatçi 13/3 (2021) 1935-1944}

Our results showed that wisdom predicted altruistic tendencies of entrepreneurs and especially affective and reflective dimensions of wisdom were the main antecedents to explain the variance in altruism. Affective dimension of the wisdom seems to be important in explaining altruism, because this dimension was included in the linear equations in all of the regression analyses conducted. This might be related with the qualities of the affective dimension as affective dimension of wisdom is about feeling sympathy, mercy and compassion for others and caring for all. Caring for people and feeling sympathy to others must be the real antecedents of altruistic behaviors. On the other hand reflective dimension of wisdom was found to be the main antecedent that differentiates the altruistic tendencies of social entrepreneurs from commercial entrepreneurs as it was not found to be predicting the altruism scores of the commercial entrepreneurs. This finding is congruent with the qualities of reflective dimension as reflective thinking is the crucial element to overcome egocentric tendencies. Examining phenomena, cases and events from many different perspectives and diminished selfcenteredness and a better understanding of others' are characteristics of reflective thinking and these are also key for feeling empathy for others which is a precursor for both affective dimension of wisdom and altruism. Reflective thinking could be an antecedent for understanding that sublime values like love, wellbeing, caring, compassion are more important than the material issues. Reflective thinking and activities like meditation which supports reflection in humans are also precursors for personal and social wellbeing and inner peace in different old and religious disciplines and spiritual trends that teaches love for all beings (e.g. loving kindness meditation). (Galante, Bekkers, Mitchell, and Gallacher, 2016).

Cognitive dimension had only a negative relationship with altruism for commercial entrepreneurs. This finding requires more inquiry as this finding is an interesting one. Future studies regarding the associations between wisdom and materialistic values can give us insights about this finding. Person's ability to understand life, being aware of the positive and negative aspects of human nature and life's unpredictability and uncertainties are properties of cognitive dimensions of wisdom. They may interact with the materialistic orientation of commercial entrepreneurs and ingenerate a negative effect on altruistic tendencies, however as previously said this requires further investigation with new studies.

The altruism comparisons showed that in terms of benevolence without material costs there was no difference between the two entrepreneur groups. All entrepreneurs deal with altruistic behaviors when there is no monetary cost. However when there is a possibility to lose money, a possibility of a material cost, that might have the capacity to create a difference between the two groups as the significant $t$-test results showed. As previously mentioned commercial entrepreneurs might not want to deal with other oriented behaviors if these behaviors cost money for them. Besides these interesting findings, our results should be interpreted deliberately as this study was a cross-sectional design in nature and we cannot derive causal relations among the variables investigated. However the differences regarding wisdom and altruism for different entrepreneurs show us that despite the common characteristics in entrepreneurial process the underlying motives and attributes are different for two groups of entrepreneurs.

Implications of this study can also be considered promising. In a rapidly changing world and chaotic atmosphere of business with its interaction among political-legal, economical, ecological, technological and socio-cultural aspects, the concept of wisdom can be considered a panacea for the survival. The main theme of social entrepreneurship and its difference from the traditional commercial ones underlines the need for holistic well-being of both individuals and businesses as living mechanisms. Specifically, affective and reflective dimensions of wisdom in explaining altruism can challenge the education system of entrepreneurship and organizational psychology in the fields of leadership, motivation and sustainable strategic planning. In such, leaders and managers can also be potential candidates for intrapreneurship which can be fostered through reflective wisdom if combined with cognitive dimensions. Apart from the educational support, organizational development efforts and HR practices can be elaborated with wisdom scales. 


\section{References}

Ardelt, M. (2000). Intellectual versus wisdom-related knowledge: The case for a different kind of learning in the later years of life. Educational Gerontology, 26(8), 771-789.

Ardelt, M. (2003). Empirical assessment of a three-dimensional wisdom scale. Research on aging, 25(3), 275-324.

Ardelt, M. (2011). The measurement of wisdom: A commentary on Taylor, Bates, and Webster's comparison of the SAWS and 3D-WS. Experimental aging research, 37(2), 241-255.

Baltes, P. B., \& Staudinger, U. M. (2000). Wisdom: A metaheuristic (pragmatic) to orchestrate mind and virtue toward excellence. American psychologist, 55(1), 122.

Batson, C. D. (1987). Prosocial motivation: Is it ever truly altruistic?. In Advances in experimental social psychology (Vol. 20, pp. 65-122). Academic Press.

Batson, C. D., Ahmad, N., \& Stocks, E. L. (2004). Benefits and liabilities of empathy-induced altruism. The social psychology of good and evil, 359-385.

Batson, C. D., Batson, J. G., Slingsby, J. K., Harrell, K. L., Peekna, H. M., \& Todd, R. M. (1991). Empathic joy and the empathy-altruism hypothesis. Journal of personality and social psychology, 61(3), 413.

Batson, C. D., \& Powell, A. A. (2003). Altruism and prosocial behavior. I.B. Weiner (Ed.), in Handbook of psychology Volume V, 463-484, Wiley.

Bierhoff, H. W., \& Rohmann, E. (2004). Altruistic personality in the context of the empathy-altruism hypothesis. European Journal of Personality, 18(4), 351-365.

Buss, D. (2011). Evolutionary psychology: The new science of the mind. Boston: Pearson Education Inc.

Carlo, G., Eisenberg, N., Troyer, D., Switzer, G., \& Speer, A. L. (1991). The altruistic personality: In what contexts is it apparent?. Journal of personality and social psychology, 61(3), 450.

Di Domenico, M., Haugh, H., \& Tracey, P. (2010). Social bricolage: Theorizing social value creation in social enterprises. Entrepreneurship theory and practice, 34(4), 681-703.

Galante, J., Bekkers, M. J., Mitchell, C., \& Gallacher, J. (2016). Loving-kindness meditation effects on well-being and altruism: A mixed-methods online RCT. Applied Psychology: Health and Well-Being, 8(3), 322-350.

Graziano, W. G., Habashi, M. M., Sheese, B. E., \& Tobin, R. M. (2007). Agreeableness, empathy, and helping: A person $\times$ situation perspective. Journal of personality and social psychology, 93(4), 583.

Hamilton, W. D. (1964). The genetical evolution of social behaviour. II. Journal of theoretical biology, 7(1), 17-52.

Huber, J. T., \& MacDonald, D. A. (2012). An investigation of the relations between altruism, empathy, and spirituality. Journal of Humanistic Psychology, 52(2), 206-221.

Kağıtçıbaşı, Ç. (2010). Günümüzde İnsan ve İnsanlar-Sosyal Psikolojiye Giriş. Evrim Yayınevi, İstanbul.

Lumpkin, G. T., Moss, T. W., Gras, D. M., Kato, S., \& Amezcua, A. S. (2013). Entrepreneurial processes in social contexts: how are they different, if at all?. Small Business Economics, 40(3), 761-783.

Mair, J., \& Marti, I. (2006). Social entrepreneurship research: A source of explanation, prediction, and delight. Journal of world business, 41(1), 36-44.

Martin, R. L., \& Osberg, S. (2007). Social entrepreneurship: The case for definition. Stanford Social Innovation Review, spring, 29-39.

Miller, T. L., Grimes, M. G., McMullen, J. S., \& Vogus, T. J. (2012). Venturing for others with heart and head: How compassion encourages social entrepreneurship. Academy of management review, 37(4), 616-640.

Omorede, A. (2014), "Exploration of motivation drivers towards social entrepreneurship", Social Enterprise Journal, 19 (3), 239-267. 
Organisation for Economic Co-Operation and Development (OECD), (1998), Fostering Entrepreneurship, Paris: OECD.

Pal Singh, S., (2007), Social Entrepreneurship: Conceptual Insights and Research Priorities, The Seventh Biennial Conference on the New Frontiers of Entrepreneurship, Ahmadabad, March 21-23 2007, Entrepreneurship Development Institute of India.

Pirson, M. (2012), "Social entrepreneurs as the paragons of shared value creation? A critical perspective", Social Enterprise Journal, Vol. 8 No. 1, pp. 31-48. https://doi.org/10.1108/17508611211226575

Rushton, J. P., Chrisjohn, R. D., \& Fekken, G. C. (1981). The altruistic personality and the self-report altruism scale. Personality and Individual Differences, 2(4), 293-302.

Saatçi, E.Y., \& Arıkan, S. (2014). Entrepreneurship education and disciplinary differences of university students in regard to their tendency to become an entrepreneur. Journal of Advanced Management Science, 2 (4), 310-315.

Saatci, E. Y., Arikan, S., \& Cal, B. T. (2014). Values? How social entrepreneurs' portrait values differ from commercial entrepreneurs?. International Journal of Education and Research, 2(9), 143-160.

Sternberg, R. J. (1998). A balance theory of wisdom. Review of general psychology, 2(4), 347-365.

Tan, W. L., Williams, J., \& Tan, T. M. (2005). Defining the 'social'in 'social entrepreneurship': Altruism and entrepreneurship. The International Entrepreneurship and Management Journal, 1(3), 353-365.

Taylor, P. D. (1992). Altruism in viscous populations - an inclusive fitness model. Evolutionary ecology, 6(4), 352356.

Taylor, S. E., Peplau, L. A., \& Sears, D. O. (2006). Social psychology . New Jersey: Prentice Hall.

Trivers, R. L. (1971). The evolution of reciprocal altruism. The Quarterly review of biology, 46(1), 35-57. 